\title{
Pengaruh upah minimum, pertumbuhan ekonomi dan investasi terhadap penyerapan tenaga kerja sektor industri di Provinsi Jambi tahun 2000-2018
}

\author{
Rita Anggraini* ; Purwaka Hari Prihanto ; Muhammad Safri \\ Prodi Ekonomi Pembangunan Fak. Ekonomi dan Bisnis Universitas Jambi \\ *E-mail korespondensi: ritaanggrainii127@gmail.com
}

\begin{abstract}
This study aims to: 1) To determine the development of labor absorption in the industrial sector, minimum wages, economic growth, and industrial investment in Jambi Province 2000-2018. 2) To determine the effect of minimum wages, economic growth, and industrial investment on labor absorption in Jambi Province 2000-2018. The research analysis tool uses multiple linear regression analysis tools. Based on the results of the $F$ test, it is known or obtained a probability significance of 0.000 is smaller than alpha 5 percent, namely 0.05. This means that the minimum wage, economic growth, and investment variables together have a significant effect on the labor absorption variable. The variable that has a significant effect on labor absorption in the industrial sector in Jambi Province is the minimum wage variable because the probability value is 0.018 where the probability value is less than 0.05 , while the variables of economic growth and industrial investment do not have a significant effect on employment in the sector. industry in Jambi Province because the probability value is greater than 0.05.
\end{abstract}

Keywords: Minimum wages, Economic growth, Investment and Absorption of industrial sector workers

\begin{abstract}
Abstrak
Penelitian ini bertujuan untuk: 1) Untuk mengetahui perkembangan penyerapan tenaga kerja sektor industri, upah minimum, pertumbuhan ekonomi dan investasi industri di Provinsi Jambi Tahun 2000-2018. 2) Untuk mengetahui pengaruh upah minimum, pertumbuhan ekonomi dan investasi industri terhadap penyerapan tenaga kerja di Provinsi Jambi tahun 2000-2018. Alat analisis penelitian menggunakan alat analisis regresi linier berganda. Berdasarkan hasil uji $\mathrm{F}$ diketahui atau diperoleh signifikansi probabilita sebesar 0,000 lebih kecil dari alpha 5 persen yaitu 0,05. Artinya variabel upah minimum, pertumbuhan ekonomi dan investasi secara bersama-sama berpengaruh signifikan terhadap variabel penyerapan tenaga kerja. Variabel yang berpengaruh signifikan terhadap penyerapan tenaga kerja pada sektor industri di Provinsi Jambi adalah variabel upah minimum karena nilai probabilitasnya sebesar 0,018 dimana nilai probabilitas tersebut lebih kecil dari 0,05 , sementara variabel pertumbuhan ekonomi dan investasi industri tidak berpengaruh signifikan terhadap penyerapan tenaga kerja pada sektor industri di Provinsi Jambi karena nilai probabilitanya lebih besar dari 0,05.
\end{abstract}

Kata kunci: Upah minimum, Pertumbuhan ekonomi, Investasi dan Penyerapan tenaga kerja sektor industri 


\section{PENDAHULUAN}

Pada umumnya pembangunan ekonomi diartikan sebagai serangkaian usaha dalam suatu perekonomian untuk mengembangkan kegiatan ekonominya sehingga infrastruktur lebih banyak tersedia, perusahaan semakin banyak dan semakin berkembang, taraf pendidikan semakin tinggi dan teknologi semakin meningkat. Sebagai implikasi dari perkembangan ini diharapkan kesempatan kerja akan bertambah, tingkat pendapatan akan meningkat dan kemakmuran masyarakat menjadi semakin tinggi (Sukirno, 2006).

Proses pembangunan menghendaki adanya pertumbuhan ekonomi yang dikuti dengan perubahan (growth plus change) dalam: Pertama, perubahan struktur ekonomi: dari pertanian menuju industri atau jasa. Kedua, perubahan kelembagaan baik lewat regulasi maupun reformasi kelembagaan itu sendiri. Potensi ekonomi suatu daerah menggambarkan sejauh mana berbagai sumber daya alam dan sumber daya manusia yang dimiliki suatu daerah memiliki kekuatan dalam memberikan kontribusi produktif terhadap pembangunan ekonomi. Sumber daya alam (SDA) meliputi pertanian, perikanan/kelautan, dan pertambangan. Sedangkan potensi sumber daya manusia (SDM), selain dalam jumlah penduduk juga jumlah pekerja.

Dalam proses pembangunan ekonomi, sektor industri dijadikan prioritas pembangunan yang diharapkan mempunyai peranan penting sebagai sektor pemimpin (leading sector), yang berarti dengan adanya pembangunan industri akan memacu dan mengangkat sektor-sektor lainnya seperti sektor jasa dan lainnya. Pembangunan ekonomi yang mengarah pada industrialisasi dapat dijadikan motor penggerak pertumbuhan ekonomi dan juga menyediakan lapangan pekerjaan bagi penduduk untuk memenuhi lapangan pekerjaan bagi penduduk dan juga memenuhi pasar kerja.

Perkembangan sektor industri di Provinsi Jambi pada tahun 2010 sektor industri sebanyak 21.683 industri dan pada tahun 2016 sektor industri meningkat menjadi sebanyak 24.479 industri. Perkembangan di sektor industri ini diharapkan memberikan dampak yang cukup luas bagi pembangunan suatu daerah. dengan tersedianya tenaga kerja dan sumber daya yang dimiliki Provinsi Jambi berpotensi untuk dikembangkannya sektor industri baik industri rumah tangga, industri kecil, industri sedang maupun industri besar. Peningkatan sektor industri tersebut diharapkan dapat meningkatkan juga penyerapan tenaga kerjanya juga yang ada di Provinsi Jambi.

Provinsi Jambi memiliki potensi alam yang cukup dalam mendukung perkembangan industri dalam dunia usaha ekonomi yang perkembangnnya semakin pesat dengan berbagai kendala yang harus dihadapi dimana setiap kendala harus dicari pemecahannya sehingga perusahaan dapat mempertahankan kelangsungan hidupnya serta berkembang secara dinamis yang kesemuanya itu akan memberikan pencapaian tujuan perusahaannya. Dengan adanya penggunaan sumber daya alam berupa modal, skill dan tenaga kerja yang cukup diharapkan dapat diperdaya gunakan dengan sebaikbaiknya.

Berdasarkan Badan Pusat Statistik Provinsi Jambi fakta yang terjadi penyerapan tenaga kerja sektor industri di Provinsi Jambi selama lima tahun terakhir mengalami peningkatan. Pada tahun 2014 penyerapan tenaga kerja sektor industri sebesar 105.999 orang. Pada tahun 2015 penyerapan tenaga kerja sektor industri mengalami peningkatan dari tahun 2014 menjadi sebesar 111.390 orang. Pada tahun 2016 penyerapan tenaga sektor industri meningkat dari tahun sebelumnya menjadi sebesar 121.694 orang. Pada tahun 2017 penyerapan tenaga kerja meningkat menjadi sebesar 121.694 orang. Pada tahun 2018 penyerapan tenaga kerja sektor industri kembali mengalami peningkatan dari 
tahun sebelumnya menjadi sebesar 126.744 orang. Dilihat dari penyerapan tenaga kerja sektor industri mengalami peningkatan setiap tahunnya, hal ini bisa jadi dipengaruhi dari faktor upah minimum, pertumbuhan ekonomi dan investasi sektor industri, hal ini diperkuat dengan penelitian Djupiansyah (2017) yang menyatakan bahwa adanya pengaruh upah minimum, pertumbuhan ekonomi dan investasi terhadap Penyerapan tenaga kerja.

Berdasarkan Badan Pusat Statistik Provinsi Jambi upah minimum di Provinsi Jambi selama lima tahun terkakhir mengalami peningkatan. Pada tahun Pada tahun 2014 upah minimum sebesar Rp.1.502.230. Pada tahun 2015 upah minimum meningkat kembali menjadi sebesar Rp.1.710.000. Pada tahun 2016 upah minimum meningkat dari tahun sebelumnya menjadi sebesar Rp.1.906.650. Pada tahun 2017 upah minimum meningkat kembali menjadi sebesar Rp.2.063.000. Pada tahun 2018 upah minimum meningkat dari tahun sebelumnya menjadi sebesar Rp.2.243.718.

Pertumbuhan ekonomi adalah pertumbuhan ekonomi diartikan sebagai kenaikan Produk Domestik Regional Bruto tanpa memandang apakah kenaikan tersebut lebih besar atau lebih kecil dari tingkat pertumbuhan penduduk atau apakah perubahan struktur ekonomi terjadi atau tidak. Setiap sektor PDRB mengalami laju pertumbuhan yang berbeda. Demikian pula dengan kemampuan setiap sektor dalam menyerap tenaga kerja. Semakin tinggi tingkat pertumbuhan ekonomi suatu sektor, maka semakin tinggi pertumbuhan penyerapan tenaga kerja sektor tersebut.

Berdasarkan Badan Pusat Statistik Provinsi Jambi pertumbuhan ekonomi di Provinsi Jambi selama lima tahun terakhir mengalami fluktuasi. Pada tahun 2014 pertumbuhan ekonomi sebesar 7,73 persen. Pada tahun 2015 pertumbuhan ekonomi menurun dari tahun sebelumnya menjadi sebesar 4,25 persen. Pada tahun 2016 pertumbuhan ekonomi di Provinsi Jambi meningkat dari tahun sebelumnya menjadi sebesar 4,34 persen. Pada tahun 2017 pertumbuhan ekonomi meningkat dari tahun sebelumnya menjadi sebesar 4,64 persen. Pada tahun 2018 pertumbuhan ekonomi di Provinsi Jambi meningkat dari tahun sebelumnya menjadi sebesar 4,70 persen.

Penyerapan tenaga kerja merupakan jumlah tenaga kerja yang bekerja dalam suatu unit usaha tertentu. Salah satu cara untuk memperluas penyerapan tenaga kerja adalah melalui pengembangan industri terutama industri yang bersifat padat karya. Perkembangan tersebut dapat terwujud melalui investasi Zamrowi (2007). Meningkatnya investasi pada suatu industri, akan meningkatkan penyerapan tenaga kerja. Karena dengan meningkatnya investasi akan meningkatkan jumlah perusahaan yang ada pada industri tersebut dan akhirnya akan meningkatkan jumlah output yang dihasilkan, sehingga permintaan tenaga kerja meningkat.

Berdasarkan Badan Pusat Statistik Provinsi Jambi investasi industri di Provinsi Jambi selama lima tahun terakhir mengalami peningkatan. Pada tahun 2014 investasi industri sebesar Rp. 15.970.000 juta. Pada tahun 2015 investasi industri meningkat dari tahun sebelumnya menjadi sebesar Rp.16.160.000 juta. Pada tahun 2016 investasi industri di Provinsi Jambi meningkat dari tahun sebelumnya menjadi sebesar 16.968.000 juta Pada tahun 2017 investasi industri meningkat dari tahun sebelumnya menjadi sebesar Rp. 17.443.000 juta. Pada tahun 2018 investasi industri di Provinsi Jambi meningkat dari tahun sebelumnya menjadi sebesar Rp. 17.989.000 juta.

Dari uraian diatas terlihat bahwa penyerapan tenaga kerja sektor industri selama lima tahun terakhir mengalami peningkatan yang diiringi dengan peningkatan upah minimum dan investasi, sementara pertumbuhan ekonomi mengalami fluktuasi. 
Seharusnya meningkatnya upah minimum akan mengurangi penyerapan tenaga kerja pada sektor industri. Begitu juga dengan pertumbuhan ekonomi yang berfluktuasi namun penyerapan tenaga kerja masih dapat mengalami peningkatan. Berdasarkan hal tersebut maka peneliti mencoba untuk meneliti jauh lebih lanjut. Adapun judul dari penelitian ini adalah ; "Pengaruh Upah Minimum, Pertumbuhan Ekonomi dan Investasi Industri Terhadap Penyerapan Tenaga Kerja Sektor Industri di Provinsi Jambi Tahun 2000-2018”. Adapun tujuan dalam penelitian ini adalah sebagai berikut : 1) Untuk mengetahui perkembangan penyerapan tenaga kerja sektor industri, upah minimum, pertumbuhan ekonomi dan investasi industri di Provinsi Jambi Tahun 2000-2018. 2) Untuk mengetahui pengaruh upah minimum, pertumbuhan ekonomi dan investasi industri terhadap penyerapan tenaga kerja di Provinsi Jambi tahun 2000-2018.

\section{METODE}

Metode penelitian yang digunakan dalam penelitian ini adalah metode analisis data sekunder berupa time series periode 2000-2018. Analisis data sekunder dilakukan dengan menggunakan data yang terlebih dahulu dikupah minimulkan oleh suatu instansi yang terkait.

Data yang digunakan dalam penelitian ini adalah data sekunder, yaitu data yang berasal dari survei yang telah diproses dan kemudian dianalisis lebih lanjut sehingga dapat menghasilkan sesuatu yang berguna. Data yang digunakan berupa rentang waktu (time series) selama periode 2000-2018 yang meliputi : Data tenaga kerja sektor industri di Provinsi Jambi, Data pertumbuhan ekonomi di Provinsi Jambi, Data upah minimum Provinsi Jambi, Data investasi industri Provinsi Jambi.

Sumber data berasal dari instansi terkait yaitu Badan Pusat Statistik Provinsi Jambi. Untuk menjawab tujuan penelitian pertama perkembangan penyerapan tenaga kerja, pertumbuhan ekonomi dan upah minimum Provinsi Jambi maka digunakan dengan rumus sebagai berikut (Halim, 2004):

Dimana:

$$
\text { PTK }=\frac{\text { PTK }_{t-} \text { PTK }_{t-1}}{\text { PTK }_{t-1}} \quad x 100 \%
$$

PTK : Perkembangan penyerapan tenaga kerja

PTK : Penyerapan tenaga kerja tahun ini

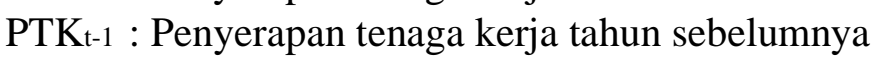

Dari persamaan tersebut berikutnya diformulasikan untuk melakukan perhitungan pertumbuhan ekonomi dan upah minimum sehingga rumus tersebut menjadi sebagai berikut :

Rumus pertumbuhan pertumbuhan ekonomi (Mankiw, 2006)

Dimana :

$$
\text { PDRB }=\frac{\text { PDRB }_{t-} \text { PDRB }_{t-1}}{\text { PDRB }_{t-1}} \quad \times 100 \%
$$

$\mathrm{PE} \quad=$ Perkembangan pertumbuhan ekonomi

$\mathrm{PDRB}_{\mathrm{t}}=\mathrm{PDRB}$ tahun sekarang

$\mathrm{PDRB}_{\mathrm{t}-1}=\mathrm{PDRB}$ tahun sebelumnya 
Rumus perkembangan upah minimum (Halim, 2004)

$$
\mathbf{U M}=\frac{\mathbf{U M}_{\mathbf{t}-} \mathbf{U M}_{\mathbf{t}-\mathbf{1}}}{\mathbf{U} \mathbf{M}_{\mathrm{t}-\mathbf{1}}} \quad \times 100 \%
$$

Dimana :

$\mathrm{UM}=$ Pertumbuhan upah minimum provinsi

$\mathrm{UM}_{\mathrm{t}} \quad=$ Upah minimum provinsi tahun sekarang

$\mathrm{UM}_{\mathrm{t}-1}=$ Upah minimum provinsi tahun sebelumnya

Rumus perkembangan investasi industri (Halim, 2004)

$$
\mathrm{INV}=\frac{I N V_{t}-I N V_{t-1}}{I N V_{t-1}} \times 100 \%
$$

Dimana :

INV = Pertumbuhan investasi provinsi

$\mathrm{INV}_{\mathrm{t}}=$ Investasi provinsi tahun sekarang

$\mathrm{INV}_{\mathrm{t}-1}=$ Investasi provinsi tahun sebelumnya

Untuk melihat pengaruh upah minimum provinsi dan pertumbuhan ekonomi terhadap penyerapan tenaga kerja sektor industri di Provinsi Jambi, maka digunakan analisis regresi linier berganda, dengan menggunakan rumus sebagai berikut :

$$
\mathbf{Y}=\boldsymbol{\beta}_{0}+\boldsymbol{\beta}_{1} \mathbf{X}_{1}+\boldsymbol{\beta}_{2} \mathbf{X}_{2}+\boldsymbol{\beta}_{3} \mathbf{X}_{3}+\mathbf{e}
$$

Dimana :

Y $\quad$ : Penyerapan tenaga kerja sektor industri

$\beta_{0} \quad$ : Nilai konstanta

$\mathrm{X}_{1} \quad$ : Upah minimum provinsi

$\mathrm{X}_{2} \quad$ : Pertumbuhan ekonomi

$\mathrm{X}_{3} \quad$ : Investasi industri

$\beta_{1} \beta_{2} \beta_{3} \quad$ : Koefisien

e : Standar error

Log : Logaritma

\section{Perkembangan penyerapan tenaga kerja}

Penggunaan tambahan tenaga kerja pada tingkat tertentu akan menghasilkan tambahan output produksi yang kemudian akan menaikkan output nasional. Tanpa adanya peran tenaga kerja maka kegiatan produksi tidak berjalan, namun penggunaan tenaga kerja yang tidak memadai juga akan mengganggu jalannya proses produksi sehingga output produksi menurun.

Berdasarkan Tabel 1 dapat dilihat bahwa penyerapan tenaga kerja pada sektor industri selama tahun 2000 sampai tahun 2018 yaitu sebesar 4,79 persen, artinya penyerapan tenaga kerja pada sektor industri setiap tahunnya rata-rata 4,79 persen pertahunnya. Rata-rata perkembangan penyerapan tenaga kerja ini cukup besar jika dibandingkan rata-rata perkembangan jumlah orang yang bekerja di Provinsi Jambi 
sebesar 2,81 persen. Tingginya rata-rata perkembangan penyerapan tenaga kerja sektor industri disebabkan sektor industri salah satu diantara 3 sektor sektor terbesar dalam PDRB, dimana produksi sektor industri memiliki kontribusi sebesar 11,26 persen.

Tabel 1. Perkembangan penyerapan tenaga kerja sektor industri Provinsi Jambi Tahun 2000-2018

\begin{tabular}{ccc}
\hline Tahun & $\begin{array}{c}\text { Penyerapan tenaga kerja } \\
\text { sektor industri (Orang) }\end{array}$ & Perkembangan $(\boldsymbol{\%})$ \\
\hline 2000 & 55.256 & - \\
2001 & 58.019 & 5,00 \\
2002 & 58.599 & 1,00 \\
2003 & 58.642 & 0,07 \\
2004 & 58.682 & 0,07 \\
2005 & 64.182 & 9,37 \\
2006 & 65.530 & 2,10 \\
2007 & 67.181 & 2,52 \\
2008 & 68.766 & 2,36 \\
2009 & 71.264 & 3,63 \\
2010 & 74.684 & 4,80 \\
2011 & 83.766 & 12,16 \\
2012 & 95.977 & 14,58 \\
2013 & 101.923 & 6,20 \\
2014 & 105.999 & 4,00 \\
2015 & 111.390 & 5,09 \\
2016 & 116.960 & 5,00 \\
2017 & 121.694 & 4,05 \\
2018 & 126.744 & 4,15 \\
\hline Rata Rata & & $\mathbf{4 , 7 9}$ \\
\hline
\end{tabular}

Sumber : Data diolah, 2019

Peningkatan tertinggi tercatat pada tahun 2012 yaitu sebesar 14,58 persen. Tingginya peningkatan tenaga kerja pada sektor industri yang tercatat pada tahun 2012 disebabkan kebijakan pemerintah yang banyak menguntungkan dan mempermudah investor terutama investor asing. Sedangkan perkembangan terendah tercatat pada tahun 2003 dan 2004 yaitu 0,07 persen. Rendahnya perkembangan tenaga kerja pada sektor industri di Provinsi Jambi tahun 2003 dan 2004 disebabkan oleh rendahnya peningkatan investasi pada sektor industri. Tenaga kerja pada sektor industri seharusnya dapat ditingkatkan setiap tahunnya karena mengingat tenaga kerja menjadi faktor untuk meningkatkan produksi.

\section{Perkembangan upah minimum}

Upah minimum adalah upah bulanan terendah yang terdiri atas upah pokok termasuk tunjangan tetap yang ditetapkan oleh gubernur sebagai jaring pengaman. Pada ini Tabel 2 perkembangan upah minimum Provinsi Jambi selama tahun 2000-2018.

Berdasarkan Tabel 2 upah minimum di Provinsi Jambi terus mengalami peningkatan setiap tahunnya, namun perkembangannya masih berfluktuasi. Rata-rata perkembangan upah minimum di Provinsi Jambi selama tahun 2000-2017 yaitu sebesar 
14,08 persen. Artinya upah minimum di Provinsi Jambi mengalami peningkatan sebesar 14,08 persen setiap tahunnya. Rata-rata perkembangan upah minimum pertahun cukup besar dikarenakan kenaikan harga barang-barang komoditi, barang-barang kebutuhan primer serta bahan bakar yang kenaikannya hampir 10 persen pertahunnya, sehingga standar upah minimum harus ditetapkan diatas 10 persen agar kesejahteraan tenaga kerja terjamin.

Tabel 2. Perkembangan upah minimum Provinsi Jambi periode 2001-2017

\begin{tabular}{ccc}
\hline Tahun & Upah minimum (Rupiah) & Perkembangan (\%) \\
\hline 2000 & 213.000 & - \\
2001 & 245.000 & 15,02 \\
2002 & 304.000 & 24,08 \\
2003 & 390.000 & 28,29 \\
2004 & 425.000 & 8,97 \\
2005 & 485.000 & 14,12 \\
2006 & 563.000 & 16,08 \\
2007 & 658.000 & 16,87 \\
2008 & 724.000 & 10,03 \\
2009 & 800.000 & 10,5 \\
2010 & 900.000 & 12,5 \\
2011 & 1.028 .000 & 14,22 \\
2012 & 1.142 .500 & 11,14 \\
2013 & 1.300 .000 & 13,79 \\
2014 & 1.502 .230 & 15,56 \\
2015 & 1.710 .000 & 13,83 \\
2016 & 1.906 .650 & 11,5 \\
2017 & 2.063 .000 & 8,20 \\
2018 & 2.243 .718 & 8,76 \\
\hline Rata-rata & & $\mathbf{1 4 , 0 8}$
\end{tabular}

Sumber : Data diolah, 2018

Perkembangan upah minimum di Provinsi Jambi tertinggi tercatat pada tahun 2003 dengan perkembangan upah minimum sebesar 28,29 persen. Pada tahun 2003 upah minimum di Provinsi Jambi yang ditetapkan sebesar Rp.304.000, nilai upah minimum di Provinsi Jambi ini naik dari tahun sebelumnya sebesar Rp. 59.000. Sementara perkembangan terendah tercatat pada tahun 2017 yaitu sebesar 8,20 persen. Pada tahun 2017 upah minimum Provinsi Jambi sebesar Rp.2.063.000 hanya naik dari tahun sebelumnya sebesar Rp. 156.000. Rendahnya perkembangan tersebut disebabkan oleh keputusan Pemerintah Provinsi Jambi berdasarkan pertimbangan asumsi inflasi di Jambi sebesar 3,07 persen dan pertumbuhan ekonomi tahun 2017 sebesar 5,1 persen.

Peningkatan upah minimum tentunya akan terus terjadi setiap tahunnya berdasarkan Peraturan Pemerintahan Nomor 78 tahun 2015 dengan tujuan untuk mensejahterakan para pekerja, namun untuk mengantisipasi beban biaya gaji karyawan maka pemilik UMKM meningkatkan target produksi mereka sehingga meningkatkan pendapatan UMKM dan mampu mengatasi beban gaji karyawan yang meningkat. 


\section{Perkembangan pertumbuhan ekonomi di Provinsi Jambi}

Pertumbuhan ekonomi adalah salah satu indikator yang digunakan untuk mengukur prestasi ekonomi suatu negara. Pertumbuhan ekonomi menggambarkan kenaikan taraf hidup diukur dengan output riil per orang. Berikut ini dapat dilihat pertumbuhan ekonomi di Provinsi Jambi selama tahun 2000 sampai 2018 pada tabel berikut ini:

Tabel 3. Perkembangan pertumbuhan ekonomi di Provinsi Jambi tahun 2000-2018

\begin{tabular}{lc}
\hline Tahun & Pertumbuhan Ekonomi $(\boldsymbol{\%})$ \\
\hline 2000 & 5,84 \\
2001 & 6,65 \\
2002 & 5,86 \\
2003 & 5,00 \\
2004 & 5,38 \\
2005 & 5,57 \\
2006 & 5,89 \\
2007 & 6,82 \\
2008 & 7,16 \\
2009 & 6,39 \\
2010 & 7,31 \\
2011 & 7,3 \\
2012 & 6,5 \\
2013 & 6,89 \\
2014 & 7,73 \\
2015 & 4,25 \\
2016 & 4,34 \\
2017 & 4,64 \\
2018 & 4,70 \\
\hline Rata-Rata & $\mathbf{6 , 0 1}$ \\
\hline
\end{tabular}

Sumber : Data diolah, 2019

Berdasarkan Tabel 3 dapat dilihat bahwa pertumbuhan ekonomi Provinsi Jambi selama tahun 2000-2018 mengalami fluktuasi setiap tahunnya. Rata-rata pertumbuhan ekonomi Provinsi Jambi selama 19 tahun terakhir adalah 6,01 persen. dikarenakan pertumbuhan ekonomi yang sangat rendah dan terjadi pada tahun 2015 hingga tahun 2018 dengan pertumbuhan ekonomi dibawah angka 5 persen.

Pertumbuhan ekonomi tertinggi tercatat pada tahun 2014 yaitu sebesar 7,73 persen. Tingginya pertumbuhan ekonomi pada tahun 2014 terjadi karena meningkatnya PDRB pada sektor penyediaan akomodasi makanan dan minum dengan signifikan yaitu dari 6,4 persen menjadi 18,73 persen. Sedangkan pertumbuhan ekonomi terendah tercatat pada tahun 2015 yaitu 4,25 persen. Rendahnya pertumbuhan ekonomi pada tahun 2015 dikarenakan turunnya produksi pada hampir seluruh sektor PDRB. Turunnya produksi dikarenakan anjloknya konsumsi rumah tangga, konsumsi rumah tangga hanya mampu tumbuh 4,96 persen.

\section{Perkembangan investasi sektor indutsri}

Investasi adalah kegiatan mengalokasikan atau menanamkan sumber daya saat ini, dengan harapan mendapatkan manfaat dikemudian hari (masa datang) untuk memenuhi 
berbagai kebutuhan masyarakat baik individu, kelompok, dan bahkan negara. Investasi dalam penelitian ini adalah investasi pada sektor industri yang dapat dilihat pada tabel berikut :

Tabel 4. Perkembangan investasi sektor industri Provinsi Jambi tahun 2000-2018

\begin{tabular}{ccc}
\hline Tahun & Investasi (Rp. Juta) & Perkembangan $\mathbf{\%})$ \\
\hline 2000 & 11.229 .610 & - \\
2001 & 11.462 .312 & 2,07 \\
2002 & 11.527 .664 & 0,57 \\
2003 & 11.862 .312 & 2,90 \\
2004 & 11.891 .468 & 0,25 \\
2005 & 11.957 .125 & 0,55 \\
2006 & 12.435 .410 & 4,00 \\
2007 & 12.886 .815 & 3,63 \\
2008 & 13.050 .478 & 1,27 \\
2009 & 13.676 .900 & 4,80 \\
2010 & 14.333 .392 & 4,80 \\
2011 & 14.417 .520 & 0,59 \\
2012 & 14.730 .379 & 2,88 \\
2013 & 15.210 .000 & 3,26 \\
2014 & 15.970 .000 & 5,00 \\
2015 & 16.160 .000 & 1,19 \\
2016 & 16.968 .000 & 5,00 \\
2017 & 17.433 .000 & 2,80 \\
2018 & 17.989 .000 & 3,13 \\
\hline Rata Rata & & $\mathbf{2 , 7 0}$ \\
\hline
\end{tabular}

Sumber : Data diolah, 2019

Berdasarkan Tabel 4 dapat dilihat bahwa perkembangan investasi pada sektor industri selama tahun 2000 sampai tahun 2018 yaitu sebesar 2,70 persen, artinya investasi mengalami peningkatan setiap tahunnya rata-rata 2,70 persen pertahunnya. Rata-rata perkembangan investasi sektor industri tersebut hanya 2,7 persen dikarenakan dalam beberapa tahun antara lain tahun 2002, 2004, 2005 dan 2011 perkembangannya hanya dibawah 1 persen.

Peningkatan tertinggi tercatat pada tahun 2014 yaitu sebesar 5 persen. Tingginya peningkatan investasi sektor industri yang tercatat pada tahun 2014 disebabkan kebijakan pemerintah yang banyak menguntungkan dan mempermudah investor terutama investor asing. Sedangkan perkembangan terendah tercatat pada tahun 2004 yaitu 0,25 persen. Rendahnya perkembangan investasi sektor industri di Provinsi Jambi tahun 2004 disebabkan oleh kelesuan ekonomi yang terjadi pada inflasi dan tingkat suku bunga. Investasi sektor industri seharusnya dapat ditingkatkan setiap tahunnya karena mengingat sektor ini menjadi sektor andalan yang dapat meningkatkan perkonomian rakyat.

\section{Pengaruh upah minimum, pertumbuhan ekonomi dan investasi industri terhadap penyerapan tenaga kerja di Provinsi Jambi}

Pada bagian ini akan dipresentasikan pengaruh upah minimum, pertumbuhan ekonomi dan investasi industri terhadap penyerapan tenaga kerja. Dengan menggunakan 
persamaan regresi berganda dan menggunakan program SPSS. Dari persamaan regresi linear berganda diperoleh hasil estimasi sebagai berikut:

Tabel 5. Hasil regresi pengaruh upah minimum, pertumbuhan ekonomi dan investasi industri terhadap penyerapan tenaga kerja

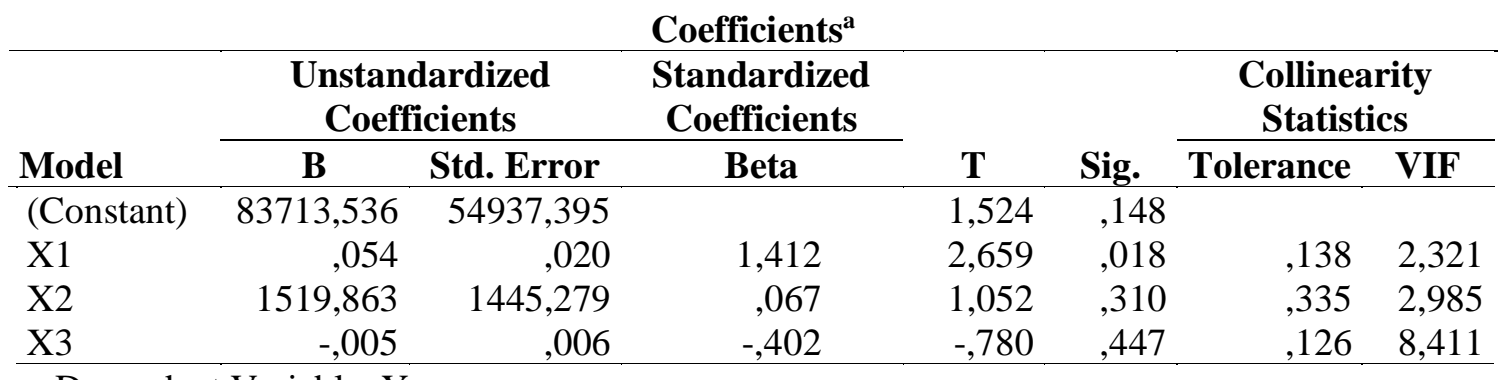

a. Dependent Variable: Y

Sumber : Data diolah, 2019

Berdasarkan hasil regresi yang dilakukan dengan menggunakan SPSS. 20, maka hasil regresi adalah :

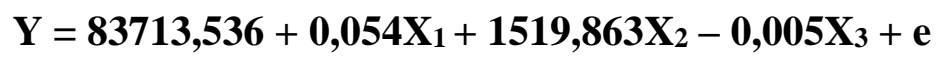

Nilai konstanta (a) sebesar 83713,536 hal ini berarti bahwa jika upah minimum, pertumbuhan ekonomi dan investasi industri adalah konstan atau tidak berubah maka penyerapan tenaga kerja sebesar 83713,536.orang, Koefesien upah minimum sebesar 0,054 hal ini berarti setiap peningkatan upah minimum satu rupiah maka penyerapan tanaga kerja akan mengalami peningkatan menjadi sebesar 0,054 orang dengan asumsi variabel lain dalam keadaaan relatif atau tidak berubah, Koefesien pertumbuhan ekonomi sebesar 1519,863 hal ini berarti setiap peningkatan pertumbuhan ekonomi sebesar 1 persen maka penyerapan tanaga kerja akan mengalami peningkatan menjadi sebesar 1519,863 orang dengan asumsi variabel lain dalam keadaaan relatif atau tidak berubah, Koefesien investasi sebesar $-0,005$ hal ini berarti setiap peningkatan investasi 1 juta rupiah maka penyerapan tanaga kerja akan mengalami penurunan menjadi sebesar -0,005 orang dengan asumsi variabel lain dalam keadaaan relatif atau tidak berubah.

\section{Uji simultan}

Uji F digunakan untuk untuk mengetahui apakah variabel-variabel independent secara bersama-sama berpengaruh terhadap variabel dependent. Pengujian dilakukan dengan menggunakan signifikansi level 0,05 $(\alpha=5 \%)$. Untuk menguji pengaruh antara variabel bebas (variabel independen) yaitu investasi dan tenaga kerja terhadap variabel terikat (variabel dependent) yaitu PDRB sektor Industri di Provinsi Jambi secara simultan digunakan alat uji F statistik yang dapat dilihat pada hasil output program SPSS 20 pada tabel ANNOVA sebagai berikut :

Tabel 6. Hasil uji F statistik

ANOVA $^{\mathrm{a}}$

\begin{tabular}{llrrrrr}
\hline Model & & Sum of Squares & Df & Mean Square & \multicolumn{1}{c}{ F } & \multicolumn{1}{c}{ Sig. } \\
\hline 1 & Regression & 10691142303,580 & 3 & 3563714101,193 & 242,339 &, $000^{\mathrm{b}}$ \\
& Residual & 220582306,420 & 15 & 14705487,095 & & \\
& Total & 10911724610,000 & 18 & & & \\
\hline
\end{tabular}

a. Dependent Variable: Y

b. Predictors: (Constant), X3, X2, X1

Sumber : Data diolah, 2019 
Berdasarkan hasil regresi diketahui atau diperoleh signifikansi probabilita sebesar 0,000 lebih kecil dari alpha 5 persen yaitu 0,05. Artinya Ho ditolak dan Ha diterima, hal ini dapat diartikan bahwa variabel bebas (upah minimum, pertumbuhan ekonomi dan investasi) secara bersama-sama (simultan) berpengaruh signifikan terhadap variabel terikat (penyerapan tenaga kerja) di Provinsi Jambi selama periode 2000-2018.

\section{Uji determinant}

Analisis koefisiensi determinasi (KD) digunakan untuk melihat beberapa besar variabel eksogen berpengaruh terhadap variabel endogen yang dinyatakan dalam persentase. Seperti yang ditunjukkan pada tabel berikut :

Tabel 8. Hasil uji $\mathrm{R}^{2}$ square

\begin{tabular}{lrrrr} 
Model & R & R Square & Adjusted R Square & Std. Error of the Estimate \\
\hline 1 &, $990^{\mathrm{a}}$ &, 980 &, 976 & 3834,77341 \\
\hline
\end{tabular}

Sumber : Data diolah, 2019

Tabel 8 dapat kita lihat model summary diketahui nilai $\mathbf{R}_{\text {square }}$ sebesar 0,980 . Nilai tersebut menunjukkan bahwa upah minimum, pertumbuhan ekonomi dan investasi berpengaruh terhadap penyerapan tenaga kerja secara simultan (keseluruhan) sebesar 98 persen dan 2 persen sisanya dipengaruhi oleh variabel lain diluar model.

\section{Uji parsial}

\section{Variabel upah minimum}

Dari hasil pengujian diperoleh nilai probabilitasnya sebesar 0,018 dimana nilai probabilitas tersebut lebih kecil dari 0,05 artinya Ho ditolak dan Ha diterima, artinya upah minimum di Provinsi Jambi berpengaruh signifikan terhadap penyerapan tenaga kerja sektor Industri di Provinsi Jambi. Dengan demikian hipotesis yang menyatakan pengaruh upah minimum terhadap penyerapan tenaga kerja sektor industri di Provinsi Jambi tahun 2000-2018 benar dan terbukti.

\section{Variabel pertumbuhan ekonomi}

Dari hasil pengujian diperoleh nilai probabilitasnya sebesar 0,310 dimana nilai probabilitas tersebut lebih besar dari 0,05 artinya Ho diterima dan Ha ditolak, artinya pertumbuhan ekonomi di Provinsi Jambi tidak berpengaruh signifikan terhadap penyerapan tenaga kerja sektor industri di Provinsi Jambi. Dengan demikian hipotesis yang menyatakan pengaruh pertumbuhan terhadap penyerapan tenaga kerja sektor Industri di Provinsi Jambi tahun 2000-2018 tidak benar dan tidak terbukti.

\section{Variabel investasi}

Dari hasil pengujian diperoleh nilai probabilitasnya sebesar 0,447 dimana nilai probabilitas tersebut lebih kecil dari 0,05 artinya Ho Ho diterima dan Ha ditolak, artinya investasi di Provinsi Jambi tidak berpengaruh signifikan terhadap penyerapan tenaga kerja sektor Industri di Provinsi Jambi. Dengan demikian hipotesis yang menyatakan pengaruh investasi terhadap penyerapan tenaga kerja sektor Industri di Provinsi Jambi tahun 2000-2018 tidak benar dan tidak terbukti. 


\section{Implikasi penelitian}

\section{Pengaruh upah minimum terhadap penyerapan tenaga kerja}

Nilai koefesien upah minimum sebesar 0,054 hal ini berarti setiap peningkatan upah minimum satu rupiah maka penyerapan tanaga kerja akan mengalami peningkatan menjadi sebesar 0,054 persen dengan asumsi variabel lain dalam keadaaan relatif atau tidak berubah. Hasil penelitian mengatakan bahwa upah minimum di Provinsi Jambi berpengaruh signifikan terhadap penyerapan tenaga kerja sektor Industri di Provinsi Jambi. Hasil ini dengan penelitian yang dilakukan oleh Atifatur (2018) yang mengatakan bahwa upah minimum berpengarauh signifikan terhadap penyerapan tenaga kerja industri. Berpengaruhnya upah minimum terhadap penyerapan tenaga kerja sektor industri dikarenakan upah minimum memiliki pergerakan yang stabil dari tiap tahunnya yang sudah disepakati oleh pihak terkait (pemerintah, pekerja, pengusaha). Peranan tingkat upah akan menyebabkan semakin banyaknya orang yang tergolong masuk ke angkatan kerja dan pengaruh positif ini juga didukung oleh adanya upah minimum provinsi yang tinggi sehingga para pekerja ikut terlibat dalam penyerapan tenaga kerja tersebut.

\section{Pengaruh pertumbuhan ekonomi terhadap penyerapan tenaga kerja}

Nilai koefisien pertumbuhan ekonomi sebesar 1519,863 hal ini berarti setiap peningkatan pertumbuhan ekonomi sebesar 1 persen maka penyerapan tanaga kerja akan mengalami peningkatan menjadi sebesar 1519,863 orang dengan asumsi variabel lain dalam keadaaan relatif atau tidak berubah. Hasil penelitian mengatakan bahwa pertumbuhan ekonomi di Provinsi Jambi tidak berpengaruh signifikan terhadap penyerapan tenaga kerja sektor Industri di Provinsi Jambi. Hal ini tidak sependapat dengan penelitian yang dilakukan oleh Tanti (2016) yang mengatakan bahwa pertumbuhan ekonomi berpengarug signifkan terhadap penyerapan tenaga kerja sektor industri. Tidak berpengaruhnya pertumbuhan ekonomi terhadap penyerapan tenaga kerja sektor industri dikarenakan disaat pertumbuhan ekonomi mengalami penurunan yang terjadi adalah penurunan produksi di sektor lain bukan disektor industri. Sedangkan sektor industri pengolahan terus mengalami peningkatan. Sehingga dapat dikatakan bahwa pertumbuhan ekonomi tidak dapat mewakili dari pertumbuhan sektor industri saja dan menurunnya pertumbuhan ekonomi tidak begitu signifikan dampaknya terhadap penyerapan tenaga kerja sektor industri.

\section{Pengaruh investasi industri terhadap penyerapan tenaga kerja}

Koefesien investasi sebesar - 0,005 hal ini berarti setiap peningkatan investasi satu juta rupiah maka penyerapan tanaga kerja akan mengalami penurunan menjadi sebesar 0,005 orang dengan asumsi variabel lain dalam keadaaan relatif atau tidak berubah. Hasil penelitian mengatakan bahwa investasi industri di Provinsi Jambi tidak berpengaruh signifikan terhadap penyerapan tenaga kerja sektor Industri di Provinsi Jambi. Hasil ini tidak dengan penelitian yang dilakukan oleh Muhtamil (2017) yang mengatakan bahwa investasi industri berpengaruh signifikan terhadap tenaga kerja. Tidak berpengaruhnya investasi industri terhadap penyerapan tenaga kerja disektor industri dikarenakan perkembangan investasi industri yang tidak terlalu besar sehingga tidak berdampak terhadap penyerapan tenaga kerja sektor industri, sehingga investasi industri tidak berpengaruh signifikan terhadap penyerapan tenaga kerja sektor industri di Provinsi Jambi. 


\section{KESIMPULAN DAN SARAN}

\section{Kesimpulan}

Berdasarkan hasil pembahasan sebelumnya, maka dapat ditarik kesimpulan sebagai yaitu rata-rata perkembangan penyerapan tenaga kerja pada sektor industri selama tahun 2000 sampai tahun 2018 yaitu sebesar 4,79 persen. Rata-rata perkembangan upah minimum di Provinsi Jambi selama tahun 2000-2017 yaitu sebesar 14,08 persen. Rata-rata pertumbuhan ekonomi Provinsi Jambi selama 19 tahun terakhir adalah 6,01 persen dan rata-rata perkembangan investasi pada sektor industri selama tahun 2000 sampai tahun 2018 yaitu sebesar 2,70 persen. Berdasarkan hasil uji $\mathrm{F}$ diketahui atau diperoleh signifikansi probabilita sebesar 0,000 lebih kecil dari alpha 5 persen yaitu 0,05 . Artinya variabel upah minimum, pertumbuhan ekonomi dan investasi secara bersamasama berpengaruh signifikan terhadap variabel penyerapan tenaga kerja. Variabel yang berpengaruh signifikan terhadap penyerapan tenaga kerja pada sektor industri di Provinsi Jambi adalah variabel upah minimum karena nilai probabilitasnya sebesar 0,018 dimana nilai probabilitas tersebut lebih kecil dari 0,05 , sementara variabel pertumbuhan ekonomi dan investasi industri tidak berpengaruh signifikan terhadap penyerapan tenaga kerja pada sektor industri di Provinsi Jambi karena nilai probabilitanya lebih besar dari 0,05.

\section{Saran}

Berdasarkan kesimpulan diatas, penulis dapat memberikan saran-saran yaitu berdasarkan hasil regresi linier berganda, bahwa yang mempengaruhi penyerapan tenaga kerja pada sektor industri di Provinsi Jambi adalah variabel upah minimum, sehingga disarankan kepada pemerintah agar dapat memperhitungkan kenaikan upah minimum setiap tahunnya dengan tidak merugikan pengusaha yang nantinya akan berdampak terhadap penurunan penyerapan tenaga kerja. Disarankan kepada peneliti selanjutnya agar mengganti variabel pertumbuhan ekonomi dan investasi industri dengan variabel lainnya yang secara teori dapat mempengaruhi penyerapan tenaga kerja terutama pada sektor industri.

\section{DAFTAR PUSTAKA}

Atifatur, Rahmawati. (2018). Analisis tingkat penyerapan tenaga kerja sektor industri di Kabupaten Gresik. Jurnal Universitas Muhammadiyah Malang. 2 (1), 74-82

Boediono. (2001). Ekonomi Makro. BPFE-UGM :Yogyakarta.

Devanto dan Putu. (2011). Kebijakan upah minimum untuk perekonomian yang berkeadilan: Tinjauan UUD 1945. Journal of Indonesian Applied Economics. 5 (2), 269-285.

Dirta, Nurlina dan Bambang, (2016). Pengaruh upah minimum, pertumbuhan ekonomi dan pendidikan terhadap penyerapan tenaga kerja di Provinsi Sumatera Selatan. Jurnal Ekonomi Pembangunan. 14 (1), 8-21

Luntungan. (2008). Analisis investasi dan pertumbuhan ekonomi di Kota Bitung. Jurnal Pembangunan Ekonomi dan Pembangunan Daerah (PEPD),1 (2), 5-6

Muhtamil. (2017). Pengaruh perkembangan industri terhadap penyerapan tenaga kerja di Provinsi Jambi. Jurnal Dinas Sosial. 2 (5), 1-12

R Nofitasari, A Amir, C Mustika. (2017). Pengaruh inflasi, suku bunga, investasi terhadap pertumbuhan ekonomi Provinsi Jambi, e-Jurnal Perspektif Ekonomi dan Pembangunan Daerah, 6 (2), 77-84 
S Romi, E Umiyati. (2018).Pengaruh pertumbuhan ekonomi dan upah minimum terhadap kemiskinan di Kota Jambi, E-Jurnal Perspektif Ekonomi dan Pembangunan Daerah, 7 (1), 1-7

Sukirno, Sadono. (2006). Ekonomi Pembangunan: Proses, Masalah, dan Dasar kebijakan, PT. Raja Grafindo Persada : Jakarta.

Sumarsono, Sonny. (2003). Ekonomi manajemen sumber daya manusia dan ketenagakerjaan. Graha Ilmu : Yogyakarta.

Tanti, Siti Rohmani. (2016). Analisis penyerapan tenaga kerja sektor industri di Provinsi Jawa Tengah. Jurnal JIEP-16, (2), 50-61

Zamrowi, M.Taufik,SE. (2007). Analisis penyerapan tenaga kerja pada industri kecil (Studi Kasus di Industri Kecil Mebel di Kota Semarang) E-Jurnal Ekonomi Pembangunan. 1 (2), 1-9. 